\title{
Tell a Story of the Nation: Image of Religion and Non-religion in the Czech National Museum*
}

\author{
TOMÁ Š BU BÍK**
}

Vyprávět přiběh národa: Obraz náboženství a bezvěrectví v Národním muzeu

\begin{abstract}
The study of religion and non-religion in a museum has become a phenomenon recently gaining attention from scholars, especially those focusing on the study of religiousness in public spaces. This paper examines the topic using the example of the Czech National Museum, particularly of its long-term exhibitions because these have a broader social impact. As a state institution, the National Museum not only collects, exhibits and studies items and artifacts but at the same time creates a story, a narrative contributing to the formation of national identity and to a sense of community. This story tries to represent Czechness in modern times, its national character, its past and present, and how it has been self-defined as well as created in relation to others. The main objective of the paper is to characterize the role of religion and non-religion in the national narrative from a Religious Studies perspective. It aims not at comparing the findings with the real importance of religion in Czech society but at uncovering how the National Museum wants its visitors to perceive the role of religion in the story of Czechness, and which events, people and values have gained a purely non-religious character in it.
\end{abstract}

Keywords: religion; non-religion; secularity; museum; nation; national identity; Czechness; religious studies

DOI: $10.14712 / 23363525.2019 .14$

It can be generally said that preservation of personally, culturally and materially valuable items rank among typical features of human behavior. The development of modern western societies in the sphere of culture, material as well as spiritual wealth and heritage has naturally led to improvement of this feature in the form of systematic and organized collecting, preservation, studying and showcasing of historically and culturally significant artifacts by means of museum exhibitions. With the rise of national awareness in Europe in the nineteenth century, national collections and museums came into existence. They have gradually been transformed into state organized and state funded institutions. The phenomenon of so-called national museums should therefore be understood not only as collecting, researching, expositional and institutional activities aimed at preservation of cultural heritage but also as an effort to co-create national awareness and identity. National museums are therefore institutions which narrate a story (or stories); we can say they create "a national narrative" (a story of the nation) based on collecting and studying cultural artifacts including those relating to or expressing a world-view - i.e. the nation's attitude to religion.

\footnotetext{
* The study was supported thanks to the Czech Science Foundation. The project GAČR with registration number 18-11345S is entitled Ateismus, volnomyšlenkárství a sekularizace v zemích střední a východní Evropy ve 20. a 21. století (Atheism, Freethought and Secularization in Central and Eastern European Countries in the Twentieth and Twenty-First Centuries).

** Assoc. Prof. Tomáš Bubík, Ph.D., Department of Sociology, Andragogy and Cultural Anthropology, Faculty of Arts, Palacký University Olomouc, tř. Svobody 8, Olomouc, Czech Republic. E-mail: tomas.bubik@upol.cz
} 
We should highlight, however, at the beginning that our aim (despite what the article's title might suggest) is not to show that religion now only belongs to a museum, i.e. that religion is merely an outdated phenomenon connected with previous generations. We are aware that religion is still part of various spheres of individual and social life (through individual believers or religious organizations), that it permeates both private and public space and is active both in ecclesiastical and in secular environments. Studying religious items, however, in a museum is specific. It is not about the penetration of the influence of religious organizations into state institutions such as the National Museum, but about the ways a public and secular institution presents (not represents) religious and world-view issues, or, in other words, what is the place of religion within the narrative of the Czech National Museum.

The Czech National Museum celebrated its bicentennial anniversary in 2018 along with the hundredth anniversary of the establishment of Czechoslovakia. Although its official name is the National Museum, we make use of the name "Czech" in the text for clarity. Although the history of this renowned research and educational institution, located in Prague, dates back to the year 1918, the only synthetic work on its history, according to Klára Woitschová, is from the 1920s by Josef Hanuš (1921 and 1923). This extensive treatment comes to an end unfortunately in the year 1842. Also worthy of mention is the work of Karel Sklenár Obraz vlasti (Picture of a Nation) from the year 2001, which is more of a popular work in terms of its character [Woitschová 2019: 85-86 ]. Woitschová, however, in light of the absence of a systematic history of the National Museum, states that "there is probably not any European museum in existence which would have a truly systematic treatment of its own history" [ibid. 2019: 93]. Despite this gap in the knowledge, there will nevertheless be an attempt here to provide the most important information from the perspective of the museum itself.

The beginnings of the National Museum are linked with renowned personages in science and culture, in particular with the figures of Count Kaspar Maria von Sternberg (1761-1838), who was a world famous paleontologist and with the famous historian František Palacký (1798-1876) as well as with an entire range of additional personages from the nation's aristocracy, from science and the arts, whose private collections donated to the museum became its basis. The activities of the museum are not limited to the natural sciences, but also encompass art-history and history. Over the course of its history, a purely scientific approach was gradually combined with a patriotic one (later a national one) as well as a popular approach [https://www.nm.cz/muzeum/o-nas/historie]. At present, the National Museum consists of, apart from its administrative sections, the Czech Museum of Music, the Historical Museum, the Natural Science Museum, the Náprstek Museum of Asian, African and American Cultures and the Library of the National Museum. These sections are then further divided into a range of scientific departments covering in terms of research extremely wide areas from prehistory and classical times up to contemporary history, from science of nature up to science of humanity. Great attention is also paid to the study of music, its personages, including musical instruments, this being apparent from the large number of expositions and exhibitions dedicated to musical issues. The collections of the museum and the exhibitions are not only located in various parts of Prague, but also in additional impressive buildings outside the capital; at present there are more 20 million specimens in the 47 museum collections. Only part of the collections are accessible to 
visitors. More than 300 specialized employees work in scholarly activities, that is administration and protection of the collections, their study and exhibiting to the public. There is no doubt that this consists of a scientific-educational institution of impressive size and importance, which in the words of the museum itself is "enhanc[ing] the sense of national identity and awareness of being part of the whole framework of European and world community and culture" [https://www.nm.cz/en/museum/about-us/history].

The above-mentioned also means that major state educational institution influence and create public opinion and public awareness of what constitutes Czechness, what it means to be Czech, how Czechs relate to others, which historical moments were defining for the formation of national identity and how they should be interpreted, what our ancestors believed in and what their traditions and customs were. The question then is what national image and what national narrative, what concept of Czechness, the museum considers representative. Who and what are the parts of the narrative, what role other nations play in it - i.e. who are the so-called important others - and how ideology, political power, skills, morals, habits, customs and religion [Buggeln - Paine - Plate 2017: 1-8] are presented, in short what constitutes national character according to the Museum - all of these questions can be asked in the context of our study focusing on what is a major national cultural institution telling us about Czech national character.

Since this consists of a theme, which has not been discussed in much detail in the Czech academic environment, there will be an attempt to outline several important theoretical issues, with the awareness, however, that they not all that novel in terms of international discussion. A text on the Czech situation would not, however, provide the needed logic without its placement within the framework of the state of research.

The first one arising in this context is the mere definition of nation and national as these are always defined in contrast to other nations. As Peggy Lewitt points out [Levitt 2015: 6-9], some nations and ethnic groups living in a particular state are, logically, not included in national museums' presentations. We can therefore justly question the representativeness of such a presentation and its validity for Museum visitors. Would it not be better to tear down ideological barriers in society rather than perpetuate them? Some might object that in the case of the Czech National Museum the representativeness is justified because the Czech Republic is currently rather homogeneous, i.e. that it is mainly Czech, even more so than it used to be in the inter-war period in Czechoslovakia. One can assume, however, that many citizens of the Czech Republic (founded in 1993), be them of Polish, German, Slovak, Vietnamese, Roma, or Hungarian nationality, as well as more recently also Ukrainians, Russians, Americans, Australians living in this country, naturally cannot identify with the National Museum's effort at a cultivation of Czech national identity and therefore pay no attention to it, unless as a curiosity. Due to globalization, world migration and intermingling of cultures, the role of national institutions will diminish, despite growing nationalism in certain countries, and thus even the well-intended missions of national museums will have to be re-evaluated.

The current significance of this type of research can be documented especially by the publication Religion in Museums: Global and Multidisciplinary Perspectives (Bloomsbury 2017), which specifically focuses on the way museums present and interpret religion, religious items, customs, or even the evolution of humans and the variety of world-views. Many museums across the world are concerned with religion as the main category of 
human culture and identity, and if not as the main category than certainly as a significant one with an important and irreplaceable position in the museums' collections and exhibitions. Clearly, museums present their visitors with religious items in one way or another, interpret them and situate them in a context. Based on the study of long-term exhibitions of the Czech National Museum and the special exhibition on the centennial of Czechoslovakia, our task is to characterize the manner and form of presentation of religious issues, the state of research on religion within the institution as well as to critically assess potential cultural biases and period stereotypes in presenting religion.

The current interest of sociologists, cultural anthropologists and religious studies scholars in the phenomenon of so-called "non-religion" has been another impulse for conducting this study. Apart from traditional attention paid to studying religion/s, the focus now is also on studying various forms of unbelief, be they modern versions of atheism, ${ }^{1}$ religious indifferentism or apatheism or so-called inCREDulous atheism. ${ }^{2}$ The recent interest in such phenomena is connected to changes modern societies are undergoing, with freedom newly understood also as freedom from religion which leads to significant differentiation among citizens on the issue of world-view practice. Thus the variety of manifestations of a secular life-style are being studied by scholars as any other life-style manifestations, i.e. they are no longer studied in opposition to religious faith in the sense of "atheisms and non-religion as antithesis to religion" [Lee 2016: 84-94] but as significant and valuable on their own terms. Therefore, apart from researching religious issues in the exhibitions of the National Museum, attention is paid to manifestations of modern non-belief and non-religion, i.e. of secular, non-religious life-styles, as self-contained world-views. As Lois Lee notes, "non-religious phenomena can be created by secularist institutions that delineate specific roles for religious actors and cultures, and by any other form of secularist ideology - articulated or enacted - that distinguishes between the religious and the non-religious" [ibid. 2016: 85].

The current study is not as much concerned with the Czech National Museum's "image of the homeland" 3 as it is specifically interested in the image of religion and non-religion in the Museum and their roles in the formation of national identity, or, in other words, in the role religion/s and generally world-views and values play in the recently presented narrative of the Czech nation (including Moravians and Silesians if they identify with Czechness). It should be noted, however, that studying museum exhibitions in general and world-view-significant items in particular is not an easy endeavor and requires a certain sensitivity. Exhibiting sacral objects in a secular space can be seen, for example, as misguided as "many believers believe that sacred objects should be available to members of

1 Phil Zuckerman (ed.), Atheism and Secularity. Santa Barbara: ABC-CLIO, 2010; T. Ngo, J. Quijada (eds.), Atheist Secularism and its Discontents. A Comparative Study of Religion and Communism in Eurasia. Palgrave MacMillan, 2015; Allan de Botton, Religion for Atheists: A Non-believer's Guide to the Uses of Religion. Vintage, 2013; Stephen Bullivant, Michael Ruse (eds.), The Oxford Handbook of Atheism. Oxford University Press, 2013; Amarnath Amarasingam (ed.), Religion and the New Atheism. A Critical Appraisal. Leiden: Brill 2010.

2 Will M. Gervais, Aiyana K. Willard, Ara Norenzayan, Joseph Henrich, The cultural transmission of faith. Why innate intuitions are necessary, but insufficient, to explain religious belief. Religion 41 (3), 2011: 389-410; Joseph Henrich, The evolution of costly displays, cooperation and religion: credibility enhancing displays and their implications for cultural evolution. Evolution and Human Behavior 30 (4), 2009: 244-260.

3 The term is borrowed from the title of a publication by Karel Sklenár., Obraz vlasti, př́iběh Národního muzea [Image of the Homeland, the Story of the National Museum]. Prague: Paseka, 2001. 
the particular religious community only" [Levitt 2015: 45]. The function of sacred items is always bound to a sacred space, to the place of the cult and to its believers and therefore makes sense only in the context of religious practice. For that reason, a museum can be considered as an outsider space ${ }^{4}$ of sorts because it is a non-religious, secular institution presenting, however, religious issues. The same objection can even be raised regarding the presentation of atheist, non-belief topics. Our research is therefore also sensitive as it poses a number of methodological and practical questions as to what and how (and if at all) certain items can be exhibited.

Attempts to answer these questions give us not only an idea about the role of religion or non-religion in the National Museum's story of the Czech nation, but also about what is preserved by the institution as formative for Czech cultural memory, ${ }^{5}$ by what scholarly research the Czech national narrative should be supported and, at the same time, what are currently the features of Czech national identity.

It should be noted that the opinion that cultural memory is above all "a reflection of contemporary problems and interests and not a reflection of historical facticity" [LužnýVáně 2017: 578] prevails at present in the social sciences. So into each story we create, we project our current issues and values. The past is perceived as "something which can be transformed, changed" [ibid. 2017: 579]. The story created by the Czech National Museum is consequently seen from this point of view, this means as a story constantly evolving, re-created, re-interpreted, revealing much more about present society, present values, world-views, the relationship to religion/s than about the past. This present history (if we can call it so) points to the fact that any image of history is always a construct co-formed by our present values and ideals, in discussion (or even in polemics) with the past.

The story is, in the first place, created in order to impress visitors, to motivate them to think about the history of their nation, to raise their awareness about what constitutes the nation's story. The particular findings are the results of field research in the form of visiting the Museum's twenty long-term exhibitions (presented in 2018) and one exhibition entitled Česko-slovenská / Slovensko-česká výstava (Czech-Slovak / Slovak-Czech Exhibition), which was opened in connection with the one hundred year anniversary of the founding of Czechoslovakia (1918-2018). Some of these exhibitions were of great importance of course in terms of content, while others were in contrast of little value.

The character of the so-called permanent exhibitions is marked by being long-term exhibitions which the Museum views as representative. They are consequently supposed to present the most interesting items which the previous generations of our collectors, researchers, scientists and artists have left behind and that which connects with the foundations and heritage of Czech culture [https://www.nm.cz/poradame/expozice]. Shortterm exhibitions, in contrast, are limited in terms of time, and are as a rule linked with one theme or event of a varying character and with the aim being to point out a certain

4 Russell T. McCutcheon (ed.), Insider/Outsider Problem in the Study of Religion (Controversies in the Study of Religion). London and New York: Cassell, 1999. The book is devoted to issues of scholarly research on religion, specifically to the problem of the position of an insider/outsider where to be an insider means to practice the religion studied while being an outsider means to make such practice one's object of study.

5 Classics in the study of cultural memory and cultural identity are works by Maurice Halbwachse La Mémoire collective (1950) and Jan Assmann Kollektives Gedächtnis und kulturelle Identität (1988). A current important work is for example The Collective Memory Reader (2011). 
interesting feature. Our attention has been focused on permanent exhibitions (only one short-term exhibition) in light of their representative character.

From the above listed reasons, there were no interviews conducted with the exhibits curators, i.e. their intentions were not studied. The main endeavor was to view the expositions as much as possible as an ordinary visitor. The author of this text is also aware, however, that he himself is not "a typical visitor", as the level of the visitor is combined with the level of the researcher (a religious studies scholar). He therefore made a maximum effort to analyze the interpretative level of the content of the exhibitions from the so-called "outside". This is not, however, to claim that only in this way can the content of exhibitions be viewed "by an ordinary visitor". The aim of this research has been to evaluate in specialized fashion how much attention was paid to the religious content, what form it took and how it was treated. And this, of course, is impossible without an academic specialization, which in the case of the author of this text was religious studies as an academic discipline as opposed to museology.

One of the objections involved in analysis of the content of long-term exhibitions could be the fact that the exhibitions came about at different times (the oldest exhibition was opened for the first time in 1905) and that its content therefore reflects the time. Much more important, however, than the time of the opening of the exhibition is in the author's view that this content is also presented to visitors at present. The impact of this content, in the same manner as is the case, for example, with school textbooks, can therefore form certain cultural stereotypes, even those which concern religious faith and attitudes to religion.

Finally, there is need to point out that there is extremely limited material on the issue of religion and non-religion in the exhibits and the selection is considerably limited. Even this fact can be viewed as an important finding. The author therefore does not agree with the view that a Museum is not a book, but only a particular communication medium. Yes, it is certainly a type of media, but also a book, and I would even go as far as to call it "a picture book", often with a truly interesting story. One cannot when studying it only focus in an exclusive fashion on the pictures, but also on the texts, that is the legends for the exhibited artifacts. The aim of this article is to therefore map out how the Czech National Museum works with religion and non-religion in the context of historical and political events, how they spoke about it and what picture they create in this context. The consequent thematic arrangement of the text does not correspond to the logic of the exhibits, but the logic of the author and his ability to examine and interpret the issue a cultural-historical context.

\section{Religion as a Relic of the Past}

The Modern era, particularly the nineteenth century during which the National Museum was established as an institution, was a period enchanted by history and by seeing reality through a historical perspective. This view has fundamentally influenced the modern study of religion as well and religion came to be understood as a historically determined phenomenon, bound to changes in society and culture, to social developments, not as a a-historical phenomenon "sui generis". The existentialist feelings of the period were alert to a religious crisis, a potential extinction of religion and the rise of a non-religious era. 
Many Czech thinkers, including T. G. Masaryk, E. Rádl, F. V. Krejčí, J. B. Kozák, V. Hoppe, F. Žilka or A. Spisar spoke about the crisis of religion [Bubík 2010: 45-73].

In the rhetoric of the temporary exhibition on the centennial of Czechoslovakia, opened in 2018 and entitled Czech-Slovak / Slovak-Czech Exhibition, such expressions appear: "religious faith and the church had been important in Czechoslovakia", 6 as if only referring to their historical significance. There is no mention of them being continuously part of social and cultural life representing a not-negligible portion of the population and influencing its opinions, values, beliefs and behavior. This attitude is in all probability responsible for the fact that disproportionately little attention is given to religious topics in various exhibits. The basic statement thus seems to be that although the religious life style was important, it was so only for our ancestors. Religion is perceived in contrast with tradition and modernity, of the past man and contemporary man, of countryman bound to nature, the soil and its cultivation on the one hand and the modern urban progressive man on the other.

Within the centennial exhibition, one section is labeled simply "Faith" but it is a rather humble one even if it considers religiousness as "a fundamental part of the national movement". The Czech Lands are presented as a country of several confessions, which is to be proven by the existence of several "national" churches after 1918. It cannot be overlooked that the exhibition is attempting to create the image of religious plurality as typical both for historical Czechoslovakia and the current Czech Republic. There can be found, for example, various items exhibited side by side: a Greek Orthodox cross, a Protestant prayer book, the liturgical vestments of Karel Farský, the Bishop and the first Patriarch of the Czechoslovak Church, a painting depicting the burning at the stake of Jan (John) Hus, or the Golden Rose awarded by Pope John Paul II in 1985 to the Basilica in Moravian Velehrad.

It is probably logical, from the point of view of the effort to cultivate national identity, that the majority of the exhibited items concern the Czechoslovak Hussite Church and the Catholic Church. There is a slight tendency to rehabilitate the Catholic Church in the eyes of the public by pointing out the courage of various Catholic believers during the communist era. Nevertheless, the presentation of religious faith in the context of this historically very important exhibition is problematic because it does not correspond to the character of the inhabitants' religiousness since 1918. It therefore provides a rather odd picture. There is no presentation of other religious groups, for example, smaller Christian denominations, nor any information on non-Christian ones, especially on Czech Jews, although members of these religious groups also participated in the formation of national identity, of modern Czech statehood and the concept of democracy. It should be noted that there are some 40 officially registered churches and religious groups in the Czech Republic at present.

6 Czech-Slovak / Slovak-Czech Exhibition. The exhibition in the Historical Building of the National Museum introduces the history of the common state of Czechs and Slovaks. The exhibition presents the story of the lives of Czechs and Slovaks in the new, shared and democratic state, in Czechoslovakia, which came about after the dissolution of Austria-Hungary in 1918. The exhibition consists of a number of sections which depict, in mosaic, fashion, this cohabitation, not only on the political level, but also in terms of everyday life. The exhibition attempts to depict both the advantages and disadvantages of this cohabitation, both what united and divided these two nations. Overall, the exhibition presents 1200 artefacts and documents. The author was most interested in the section aptly entitled "Faith". 
Another fact might come as a surprise to the exhibition visitor - despite Czechoslovakia's emphasis on the secular concept of the state and statehood, on a plurality of values, very little attention is paid to citizens without a confession, to members of the cremation movement as well as to Free Thought. All this is represented by two items only (a poster of the Cremation Association, the flag of the left-wing Association of Proletarian Non-believers). The Czech non-belief movement was, however, highly diversified. At the time of early Czechoslovakia, the movement's membership was numerous (up to ten thousand at its peak) and very active, both nationally - participating in efforts at democratization of the Czech education system, politics, and cultural life - and internationally. The exposition of the 1931 flag of the Association of Proletarian Non-believers is even accompanied by the wrong label claiming that it is the flag of the Association of Political Non-believers. Further explanation or context information is missing completely. Overall, therefore, this exhibition does not create all that serious a picture of the importance and place of religion and non-religion in the lives of the inhabitants and in society.

From our point of view, the long-term exhibition entitled Czech Folk Culture, ${ }^{7}$ which opened in 2005 and located in the Ethnographic Museum of the National Museum, is far more interesting both in terms of the artifacts presented and the image of religiousness it conveys. Religion is presented as closely related to folk, rural culture, as a typical feature of the countryside. At the same time, the folk form of religion is characterized as a mingling of pre-Christian elements with Christianity into an organic whole. The aim of the exhibition is thus not to emphasize the importance of Christianity nor of pre-Christian traditions but to show folk culture in its entirety, as interconnecting both traditions and customs.

In the Czech context, the folk form of religious faith and religiousness is often labeled as a traditional value as well as a form of habit, i.e. a customary faith which can be replaced by other customs and traditions. Perhaps for this reason religion is only referred to in the past tense. Interestingly enough, the development of religious traditions in the Czech Lands is not seen in the oppositions of Christian/Czech as one might expect. The opposition, nevertheless, is apparent in the presentation of folk religious faith in contrast to the official church faith associated mainly with Austrian Roman Catholicism, as we shall discuss later.

The exhibition displays human life and objects from birth to death marked by key rituals: baptism, first communion, weddings and funerals. Weddings, in particular, are still seen as a stable milestone of human life, one of the most significant rites of passage. Rural folk religiousness combines, as mentioned above, both natural and official, church faith, both pre-Christian and Christian elements. Easter was, for example, both a Christian holiday and a pre-Christian celebration of spring and regeneration. Other traditions combining pre-Christian and Christian elements are connected with the changing of the seasons, such as the ritual of taking the effigy of Death (Morana) out of a village to celebrate the end of winter and the arrival of spring; or the bringing of a new summer, where

7 This consists of an ethnographic exhibition opened to the public in 2005, which presented the life in the countryside in the Czech Lands and in Moravia in the eighteenth, nineteenth and first half of the twentieth century. It consisted of a presentation of material culture, folk and religious traditions and the main stages of human life consisting of in particular birth, weddings, dying and death. The exhibition aims at capturing the character of folk culture, which links within itself pre-Christian and Christian traditions, with an attempt to demonstrate what our ancestors believed in. 
the Christian Pentecost is combined with the summer solstice. The season of advent is also seen as a mixture of church traditions and natural elements. Thus so-called folk religious faith is a combination of the natural and the ecclesiastical, of magic pre-Christian rituals and Christian rituals. Such a form of religiousness is presented by the Museum as part of Czech folk culture and the Czech nation, as a specific spiritual world of rural people, "the rural world of past generations".

Apart from this, the exhibition highlights the importance of labor, both farm work and crafts in the cycle of human life as it influences it to a far greater extent than holidays. Christianity is thus seen not only as a religion of ancestors, but as a kind of culture alternating ordinary days and holidays, in other words the time of work and the time of rest. The exhibition specifically points out the importance of human labor and activities in subduing nature and in making one's life more comfortable. The ultimate fulfillment of human life is therefore presented as grounded in work. The major message of the exhibition thus appears to be the increase in happiness and the diminishing of hardship thanks to work and the subjugation of nature. Interestingly enough however, the expressions "subjugation" and "conquest" of nature show a man in opposition to nature and are not in accord with either the folk religious faith nor with the traditional Christian concept of man as a keeper of nature, as a being living in a good, God-created universe.

In the context of the exhibition, nature is explained purely materialistically (if not necessarily in the way of historical materialism of Marxism-Leninism) as a supply of resources which men transform through their activities, and as a manifestation of human creativity and skills in this transformation. The exhibition therefore speaks of human creative power in producing the goods and instruments needed for existence. Man is seen as a link between natural resources and life necessities, a claim that truly resonates with Marxism. Labor is also fundamental as a unifying agent in society and in social relationships. Thus while human beings were viewed as religious beings (or beings with religious needs), now man is rather seen as a being of labor, as "homo faber", as man-the-conqueror. Clearly, the ideological framework of the exhibition is rather outdated and is not in accord with the recent approaches and possibilities in interpreting the items exhibited.

Apart from the values described as traditional (most likely meaning Christian), so-called elementary values are stressed such as those directly connected with the relationship between humans and nature. These elementary values are then explained as results of the geographical situation of the Czech Lands as the "crossroad of cultural paths" and as a result of the "mountainous and sub-mountainous regions" 8 which, due to concerns over survival, gave rise to pre-Christian religious concepts. ${ }^{9}$

Cultural influences, together with the personification of natural forces and mountain peaks, supposedly resulted in the formation of certain religious ideas, the most remarkable of these being the male figure of Krakonoš, the guardian of mountain treasures, helper of good people, and also the patron of justice and morals, often portrayed as a wooden effigy.

8 Long-term exhibition Czech Folk Culture. Ethnographic exhibition of the National Museum in Prague.

9 Among the first world-renowned works on the origins of religion are: Primitive Culture. Researches into the Development of Mythology, Religion, Art and Custom 53 (1871) by Edward B. Tylor, and Principles of Sociology (1876-86) by Herbert Spencer. The book by Julius Lippert Der Seelenkult in seinen Beziehungen zur Althebräischen Religion; Eine ethnologische Studie (1881) is considered the most concise and detailed work, especially in relation to the Semitic nations. 
In this context, woodcraft is mentioned as one of the typical skills of Czech folk, central to many crafts (carpenter, cartwright, cooper, shingle maker, mangle maker, wood-carver). As a characteristic manifestation of the confluence of human creative potentials, folk carvings of nativity scenes (crèches) are mentioned, together with production of wooden figures of the Virgin Mary or saints.

The Museum's concept of religion as a relic of the past is also apparent in another longterm exhibition on Czech Bell Founding, ${ }^{10}$ designed as the history of the bell founding craft in Bohemia and Moravia. Apart from items of daily use such as door knockers and mortars, the exhibition presents a collection of church bells, liturgical bells, baptismal fonts, etc. Another exhibition Lapidarium - Monuments of Stone Carving in Bohemia from the Eleventh to the Nineteenth Centuries, first opened in 1905 and housing the largest open to the public collection of stone carvings, architectural items and sculptures from Prague and Central Bohemia, is a similar case. ${ }^{11}$ It contains both secular and sacred artifacts, symbols of political as well as ecclesiastical power. Among these is the torso of the Marian Column from the Old Town Square in Prague and the statue of Franz Joseph I originally located in the Main Railway station in Prague. A specific aspect of Czechness and of Czech national identity is the attitude to Catholicism and to the Habsburg Empire as can be seen in various exhibitions. This is documented in the previously mentioned centennial exhibition, for example, by a damaged portrait of the Habsburg Emperor Franz Joseph I or by the torso of the Marian Column. As symbols of religious and political power, both monuments were removed shortly after the declaration of an independent Czechoslovakia in 1918. The issue of the return of the Marian Column to its original public place has been a topic of public discussions ever since. ${ }^{12}$

Both these exhibited items also illustrate that even in the contemporary story of the Czech nation, created by the National Museum, an important role is played by efforts to free the nation from the monarchic rule of the Habsburg Empire and "the symbols of the Habsburg rule over the Czech Lands" as the exhibition puts it. The case of the Marian Column documents the problematic attitude of part of the Czech population towards the Catholic Church, even to religion in general, as well as the fact that this divides the Czech population and also differentiates it from the Slovak nation. ${ }^{13}$

10 Czech Bell Founding: The Production of Bells in the Territory of Bohemia and Moravia. National Museum long-term exhibition in Vrchotovy Janovice Chateau. The exhibition collects more than 150 items such as door knockers and mortars and presents a collection of church bells, liturgical bells and baptismal fonts.

11 Lapidarium - Monuments of Stone Carving in Bohemia from the Eleventh to the Nineteenth Centuries. The exhibition is located in the building of the Lapidarium of the National Museum and chronologically presents sone of the finest artistic creations of this period in the Czech Lands. These are stone sculpture artefacts such as reliefs, sculptures, grave stones, monuments, columns, sculptural groups, etc.

12 There have been several failed attempts to re-erect the column.

13 The attitude to religion divided the dissent as well, because the Czech one was far more secular and political. The exhibition does not omit the persecution of churches and believers under the communist regime and repeatedly emphasizes the difference between the Czech Lands and Slovakia, where "faith and churches managed to preserve a strong position in society". The visit of Pope John Paul II in 1990 is noted as a milestone for future cooperation. 


\section{National Heroes as Role Models for the Formation of National Identity}

It has already been stated that within the National Museum exhibitions, religiousness is presented as an aspect of national identity in the past as can also be proven by the number of historical items related to biblical figures or important saints whose life stories were somehow connected to Czech history or were popular here. These include in particular St. Wenceslas, John Huss and the Hussite Movement, St. John Nepomucene or St. Anthony of Padua, this being particularly visible in the exhibition Czech Folk Culture. The exhibitions create the impression, however, that religion is no longer a part of national identity and that contemporary figures and patterns of social behavior are different than those of the past. This part of the Museum's narrative points to the fundamental changes taking place in Czech society at this time. What is the role of religious figures in the current national narrative? What patterns of behavior and heroes are representative of the National Museum's narrative for modern times?

First, the situation will be outlined historically for a better understanding of the context. The National Museum introduces five key historical milestones in the twentieth century which fundamentally influenced the character of Czech and Slovak statehood - none of these refers to the role of Christianity or religious faith nor has any religious dimension. These milestones are the years 1918, 1938, 1945, 1948 and 1989. The long-term exhibition reflects these milestones and also important figures of Czech society. It was opened in 2011 at the National Memorial on Vítkov Hill and is entitled Crossroads of Czech and Czechoslovak Statehood.

Inter-war Czechoslovakia was a multinational, multi-ethnic state where, apart from Czechs and Slovaks, a "minority" of several million Germans, hundreds of thousands of Hungarians, as well as Poles, Jews, Romani, Rusyns (Ruthenes), Ukrainians, Croatians and other minorities lived. For a state institution to highlight only Czechoslovakian statesmen in the multinational context of Czechoslovakia is highly problematic in the first place. In the context of our research, however, we shall not pursue this farther but will focus on the presentation of figures regarded as prototypes of Czechness even at present, in other words, figures who hold an "ideal" (or idealized) status of the national character seen as a role model to be respected and followed. We shall mention their respective world-views including their attitude to religion.

All the figures are important personages of Czechoslovak politics and statehood. Nevertheless, none of them was a religious figure. The founders of the Republic and people who fought for freedom and democracy, and/or even suffered by or were victims of totalitarian regimes, are considered the most important. We call this aspect of the National Museum's narrative a non-religion one.

One of the most significant figures of modern Czech history is the first President of Czechoslovakia Tomáš Garrigue Masaryk, who is presented in several different exhibitions. The term "Masaryk's Republic" is even used on occasions. Interestingly enough, Masaryk's attitude to religion remains, for the Museum's visitors, undecipherable and unknown although I personally believe that it is key to understanding his thinking as well as his politics in inter-war Czechoslovakia, including his concept of the national character. Although Masaryk was baptized as Roman Catholic, he was highly critical of Roman Catholicism as represented by the Habsburg Monarchy. He was, however, deeply religious 
and considered religion his most significant life issue. The Protestant theologian Josef L. Hromádka poignantly characterizes Masaryk's attitude to religion in his Masaryk (1930):

Masaryk is our greatest philosopher of religion. His entire literary work is an ongoing polemic against religious indifference, against hypocritical religious formalism, against the official character of the church, against violence and state pressure in matters of religion, against theological myth and traditionalism. [Hromádka 1930: 129]

The question then arises as to why Masaryk's world-view orientation is not more apparent in the Museum exhibitions. In this regard, the historical memory of the Museum is blurred and unclear to visitors.

Other important figures presented in the Museum's exhibitions include Edward Beneš (1884-1948), Masaryk's successor in the presidency, Alois Rašín (1867-1923), politician and economist and first Czechoslovak Minister of Finance, and the Slovak Milan Rastislav Štefánik (1880-1919), the first Czechoslovak Minister of the Military. All three were closely connected with Tomáš G. Masaryk. They signed the Washington Declaration on 18 October 1918 which is the declaration of the independence of Czechoslovakia, and participated in all the politically significant matters preceding the Declaration. Their religious affiliation and their attitude to religion is not mentioned in the exhibition thus implying that their religious faith played no significant role in their efforts to assert Czechoslovakian statehood.

The Declaration, which is on display in the exhibition Czech-Slovak / Slovak-Czech Exhibition, similarly to various declarations of ex-patriot associations in North America and Russia, confirmed the phenomenon of so-called Czechoslovakism, i.e. the shared desire of Czechs and Slovaks to live in one state. Interestingly enough, the Pittsburgh Agreement, the Czech-Slovak memorandum of understanding, also signed by the Association of Czech Catholics, does not refer to the importance of religious faith, religion or churches in public life in any of its general principles. The main emphasis is on administrative autonomy, official language and democracy. ${ }^{14}$ Thus national identity was defined mainly in terms of language, culture and social organization, despite the fact that religious identity played a key role in the case of Slovaks and Moravians, that is, it is defined non-religiously and secular.

Another noteworthy monument contributing to the formation of national identity and preservation of national memory is the Museum's National Memorial on Vitkov Hill in Prague. Erected between 1928 and 1938, the memorial is an architecturally remarkable structure dominated by the equestrian statue of the Hussite commander Jan Žižka. The memorial is shaped as a temple, especially in its layout, with a central hall reminiscent of a nave and a Chapel to Slain Soldiers. There was even a mausoleum in the building. The original aim of the memorial was to honor Czechoslovak legionaries of WWI who militarily supported the founding of Czechoslovakia. It was also supposed to honor Italian, French, Russian and Serbian legionaries who fought against the Habsburg armies, alongside Czechoslovakians.

14 Signed on 31 May 1918, the Pittsburgh Agreement was a shared memorandum of the Slovak League of America, the Association of Czech Catholics and the Czecho-Slovak National Council under the presidency of Tomáš Garrigue Masaryk who formulated the text of the memorandum. 
After 1948, the Memorial became an object of communist propaganda, part of the "cult of the communist regime's power" as is shown in one of the exhibition's label of another exhibition Laboratory of Power ${ }^{15}$ (opened in 2012). Thus the importance of the WWI legionaries for the establishment of Czechoslovakia was to be forgotten. In the mausoleum of the exhibition, even the first communist president Klement Gottwald ${ }^{16}$ (1896-1953) was temporarily buried. The exhibition critically assesses, however, that although communism was based on "collective leadership" it nonetheless "placed their leaders in the position of beings to be adorned". Gottwald, as the label reads, was considered in his era not only "the first proletarian president, but a comrade keeper, a comrade father, the first workman, the first warrior for peace or the most beloved son of the Czechoslovakian nation" [Laboratory of Power / Mausoleum].

In the story shown in the exhibition Crossroads of Czech and Czechoslovak Statehood not only politicians are seen as important figures, but also the victims of politics, i.e. the victims of the Fascist and communist totalitarian regimes. The national narrative is critical of both systems. The destruction of the village of Lidice, the murdering of their inhabitants and the courage of the Czech and Slovak agents who assassinated high-ranking Nazi official Protector Reinhard Heinrich in 1942 are seen as symbols of the resistance to fascism. Milada Horáková (1901-1950), lawyer, and politician, and Heliodor Píka (1897-1949), general of the Czechoslovak Army and prominent representative of the foreign Czechoslovak anti-Nazi movement, both executed during communist political trials in the 1950s, are presented in the exposition as symbols of the anti-communist resistance.

The year 1968 is associated with the figure of the Charles University student Jan Palach (1948-1969), whose self-immolation was a political act of protest against the Soviet occupation of Czechoslovakia. He became a so-called human torch symbolizing resistance to totalitarianism. His aim to "wake up society against the compromises of the Czechoslovakian government towards the occupants (Russians)" is particularly highlighted. In a way, he can be perceived by the Museum's visitors as a contemporary John Hus.

Apart from Palach, Horáková and Píka, the signatories of Charter 77 are emphasized, among them especially Václav Havel (1936-2011), the first democratic president after the fall of the communist regime. In another exhibition Czech-Slovak / Slovak-Czech Exhibition, the sweater Havel was wearing on the first days of the Velvet Revolution is showcased almost as a relic. In the exhibition Crossroads of Czech and Czechoslovak Statehood, one of the few references to religious issues is connected with Charter 77 which pointed out, among other issues, religious freedom and its infringement by the communist regime including "restrictions put on the work of pastors and priests, persecution of citizens due to their religious activities, suppression of religious education, etc.". Apart from Havel, the philosopher Jan Patočka (1907-1977) who died following an exhausting interroga-

15 Laboratory of Power / Mausoleum. Long-term exhibition in the National memorial on Vítkov hill. The exhibition was opened to the public in 2012. The exhibition commemorates the legacy of communist totalitarianism and the first communist president Klement Gottwald.

16 In 1953, the first communist president Klement Gottwald was buried there, his remains were embalmed, similarly to Lenin's and Stalin's remains. Gottwald's body was cremated, however, in 1963. In 1956, Nikita Khrushchev criticized this form of adoration of politicians as "a cult of personality". Between the years 1953 and 1964, Khrushchev was the first Secretary of the the Communist Party of the Soviet Union. The change in the course of Soviet politics impacted Czechoslovakia as of the beginning of the 1960s. 
tion by the secret police, the Nobel prize-winning poet Jaroslav Seifert (1901-1986), and the writers Josef Škvorecký (1924-2012) and Pavel Tigrid (1947-2003) are listed among important figures of Czech dissent.

The exhibition Crossroads of Czech and Czechoslovak Statehood also demonstrates that Czech national awareness was formed not only thanks to significant personalities but also due to organizations and institutions supporting Czech(oslovak) statehood. An important role was also played by Czechoslovak, Italian, French, Russian, and Serbian legionaries, the Scout organization and, especially, Sokol ("falcon" in English), ${ }^{17}$ an all-age gymnastics organization which soon evolved into a "combative institution despite the fact that the Greek ideal of kalokagathia was at its foundation" and which is presented in connection with the establishment of national military units of the future Czechoslovakian army. Sokol is viewed as an important element of national unity in key historical moments in the formation of democratic Czechoslovakia. Nevertheless, its members' often negative attitude to religion (to Catholicism in particular) was problematic and eventually inspired the founding of a similarly oriented Catholic organization named Orel ("eagle" in English), supporting, in contradiction, the concept of non-national monarchism.

Apart from Sokol, the Scouts are regarded as another important organization promoting nationalism. The Czech Scout movement ${ }^{18}$ was established as part of the international movement supporting youth in their physical and mental development, emphasizing the importance of outdoor activities, of nationalism, freedom and independence and respect for other people. Both Sokol and the Scouts had been banned (due to both Nazism and communism) and re-established several times.

The National Museum and its story seem to understand the formation of national identity and the choice of national role models in two ways. Firstly, great emphasis is placed on the examples of people who fought for the nation and were even ready to sacrifice their lives, be they members of the Hussite movement in the past, or legionaries and statesmen in modern times. Nationalism is therefore closely connected with a sacrifice for the nation and the homeland, both in combat and in the battlefields of politics. Secondly, the "true" national character is not narrowly interested to national interests only but struggles for freedom, democracy, humanist ideals, and human dignity in general, and without an emphasis on religious consciousness. Such a double focus supports "the sense of national identity and awareness of being part of the whole framework of the European and world community and culture" as the Museum states in its mission. ${ }^{19}$ Such an emphasis in the displays of the National Museum can be considered a significant change in the values of the Czech society of the twentieth century and can be viewed as a move to the secular or non-religion concept of personal and social life.

\section{Music as a New Manifestations of Czechness}

Attitudes to music and the musical arts are presented as a significant part of Czech culture as documented by a traditional Czech locution "every Czech is a musician". It is

17 Founded in 1862 by Miroslav Tyrš and Jindřich Fügner.

18 Founded before WWI by Antonín Benjamin Svojsík.

19 https://www.nm.cz/en/museum/about-us/history. 
not our purpose to argue to what degree the locution is justified, but we shall focus on the presentation of music in the National Museum in the sense of how it is viewed as a feature of the national character and if it is important for the formation of national identity and the religious or secular way of life. At first, the arts as such will be discussed in a philosophical and cultural context.

Tomáš G. Masaryk is undoubtedly the central figure of the modern Czech national narrative. In his time, he ranked among the most inspirational personages in the sphere of philosophy and politics and viewed religion as the main theme of his thoughts. He rejected, however, the old, church-based form of religion and contemplated a new religion. Masaryk refused to call his concept of new religion scientific but at the same time he required science and religion (here he meant theology) not to be in conflict. He promoted the idea of non-revealed religion corresponding to the moral progress and social awareness of the most noble-minded people. Speaking of so-called humanist religion, Masaryk named Augustin Smetana (1814-1851), theologian and philosopher, as its great representative because Smetana provided the idea of humanity with its content [Masaryk 1900: 11]. Smetana thought that in the future, religion would be replaced by the arts because they share the same content, and the transition would take place within the inner life of humankind only: "The man of the past is a religious man, absorbed in the adoration of the Godly, but the man of the future shall be an artistic man" [Smetana 1903: 23-24; Bubik 2010: 59-69].

Such ideas took hold among Czech freethinkers of the twentieth century as well because they discussed religious matters freely, openly and in a new, original way. Some of them believed that the new religion would have its own priests whose temple would be nature. The priests of the new religion would be important Czech artists, for example the poet and writer Svatopluk Čech or the composers Antonín Dvořák and Bedřich Smetana [Štolfa 1927: 62-72; Bubík 2010: 59-69].

The degree and in what form the phenomenon of the arts is part of the National Museum's story of the Czech nation and its concept of national identity is clearly manifested in the notice boards of the Czech Museum of Music, ${ }^{20}$ division of the National Museum: "200 years of the National Museum, 100 years of an independent Czech state, and Music."21 Thus music is related to the Czech nation as the expression of its thoughts and sensibility, as the foundation of its relationships, especially the relationship to the homeland.

It is therefore no coincidence that there are many long-term exhibitions within the National Museum organized in its branches and devoted to Czech musicians and other artists; music, however, clearly prevails. Out of the twenty long-term exhibitions presented in 2018, six focus on music, four of them on Czech composers such as Bedřich Smetana ${ }^{22}$

20 The Czech Museum of Music itself contains some 23 thousand items.

21 Člověk - nástroj - hudba [Man - Instrument - Music], long-term exhibition of the Czech Museum of Music opened in 2004 is dedicated to various kinds of musical instruments, string and woodwind or keyboard. The collection includes historical and modern musical instruments, including recordings of their sounds, and attempts to highlight the interconnection between human craft skills and its musical expression needs.

22 The Bedrich Smetana (1824-1884) exhibition (opened in 1998) and is located in Prague. It focuses on his life and work and captures the key stages of his life including for instance sound samples of his compositions, personal correspondence, musical manuscripts and personal items. 
(1824-1884), Antonín Dvořák ${ }^{23}$ (1841-1904), Josef Suk ${ }^{24}$ (1874-1935) and Jaroslav Ježek ${ }^{25}$ (1906-1942). Due to the number of expositions, significant attention will be given to this issue.

The attitude to music is therefore presented as an important aspect of modern Czechness and plays an important role in the national narrative. One of the labels reads: "The twentieth century is the time of the search for new forms of expression by which music would voice deep changes in the lifestyle, sensibilities and attitudes of modern man." The text clearly resonates with what was stated above. In this context, music is important not only aesthetically, but for the formation of the national character, its spiritual life and its values. It is the expression of the national character. In this respect, it can substitute for religion, i.e. the religious emotions of the past would be substituted for by the artistic emotions of the present, as some thinkers have suggested. National identity thus obtains a new dimension.

The celebrated Czech composer Bedřich Smetana, to whom one entire long-term exhibition is dedicated, clearly captures the importance of music as the expression of the national spirit. According to Smetana, music should mediate not only the musical skills in handling the instrument but the manifestation of originality, of musical genius. In 1880, several years before his death Smetana wrote: "We Czechs are not only skilled musicians as other nations have called us saying that the talent is in our fingers but not in our brains; we are, however, talented with creative power and yes, we have our own specific music." 26 The world-traveled Smetana points out the originality of the Czech nation and its intellectual abilities, its creative powers in the sphere of music in contrast to mere skills in producing music. The nation therefore should be characterized by its unique character and originality.

In the context of our previous reflections on the importance of Czech folk as the bearer of genuine Czechness, Smetana's attitude to country folk should be noted. He took inspiration there often. In The Bartered Bride opera, considered a national opera, the life of Czechs is presented as a life full of music. Thus the Czech nation can be characterized as artistic, with a deep rooted spiritual need for music.

Smetana viewed himself as a Czech, a patriot who strived to support the idea of Czech national independence through his musical works both at home as well as abroad. Significantly, one of the obituaries labels him as "the father of Czech national music" and as "the genius of the Czech nation". 27 The fact that he was generally perceived as the father of national music is well illustrated by the sheer amount of monuments, busts and

23 The exhibition The Paths of Antonín Dvorák (opened in 2012) focuses on his rich life and travel in the United States and Europe. The collection includes a number of his personal items, including the composer's photographs, compositions, piano, manuscripts and other valuables. The museum is housed in the Baroque Summer Palace America in Prague's New Town.

24 The exposition Josef Suk Memorial in Křčovice (opened in 2008) is located in his own house in Křečovice, where Josef Suk spent a significant part of his life. The monument was opened in 1951 and reopened in 2008 after reconstruction. The exhibition, which consists of his personal and family objects and valuables, is dedicated to Suk's composer's work.

25 The Exposition Jaroslav Ježek Memorial or the Blue Room (opened in 1983), where the famous Czech composer lived and worked (1906-1942) is located in Prague. It was originally part of his private flat furnished in the Functionalist style from the early 1930s. The exhibition includes the original desk, piano, library and other personal items.

26 As quoted on the exhibition label in the Bedřich Smetana Museum in Prague.

27 See the exhibition in the Bedřich Smetana Museum in Prague. 
sculptures which appeared after Smetana’s death throughout Bohemia, Moravia and even Silesia (this is well documented by a photographic exhibition "Smetana Forgotten in Stone", ${ }^{28}$ a temporary exhibition in the Bedřich Smetana Museum, a division of the National Museum).

National identity was reflected in songs as well. Many composers celebrated the founding of independent Czechoslovakia by composing "songs inspired by the event, by the personality of President Masaryk or Czechoslovak legionaries" 29 including attempts at a new national anthem. Similarly, music was composed for the Sokol mass gymnastic festivals ("slets"), for the newly established Czechoslovak army or for legionaries' celebrations. A book collection of songs for various (national) celebrations is among the most interesting items in the Museum (the book includes the national anthem, songs celebrating John Hus, the old Hussite war song "Ye Who Are Warriors of God", songs to celebrate Mother's Day and others). ${ }^{30}$ Songs celebrating legionaries played an important role as well, for example the "Song of Legionaries", "the Czech Lion Has Woken Up", or a song entitled "Zborov" after a significant battle of WWI involving Czechoslovak legionaries. Celebrating nationalism and patriotism and the need to have one's homeland free and defend it, if necessary even by military force, these songs are war-like in their character. The song "To Our Father Masaryk" composed by Karel Hašler is dedicated, for example, to the Czechoslovak army and emphasizes Masaryk's role in the independent republic as well as the national determination to protect the republic and fight for it:

Our father Masaryk

Rely on your children!

Call them any time

To fight for the Republic!

Battalion after battalion

All will sing together:

Our father Masaryk

Rely on your children!

One part of the exhibition commemorating the centennial of the founding of Czechoslovakia as well as of the Czech Museum of Music is devoted to the national anthem which is supposed to express the spirit of the nation. The anthem consists of two parts - the first one is the first stanza of a song originally included in a theater play ${ }^{31}$ in 1834 :

Where is my home,

where is my home?

Water roars across the meadows,

Pinewoods rustle among crags,

The garden is glorious with spring blossom,

Paradise on earth it is to see.

28 The exhibition "Smetana Forgotten in Stone", a temporary exhibition in the Bedřich Smetana Museum.

29 See the exhibitions in the Czech Museum of Music.

30 The collection of songs entitled Our Celebrations was compiled by Jan Puchta in 1936.

31 Written by Josef Kajetán Tyl, the play Fidlovačka aneb Žádný hněv a žádná rvačka [Fidlovačka, or No Anger and No Brawl] opened in 1834 in Prague in the Estates Theater. 
And this is that beautiful land,

The Czech land, my home,

The Czech land, my home. ${ }^{32}$

Interestingly enough, this part of the anthem primarily emphasizes the beauty of the homeland's landscape and is not derived from a war song or a marching song. It instead celebrates the countryside, compares it to paradise and emphasizes that our land, the Czech land, is the best place to live. Although originally the song had two stanzas, the second one containing religious motifs, only the first one became so popular as to be turned into the national anthem. The general public usually does not even know the words of the second stanza, even if the original song was not all that long and could have been easily remembered in its entirety. The length then probably did not play a role in turning only the first stanza into the national anthem. ${ }^{33}$ Despite many critical voices and some active attempts to create a new anthem with the establishment of the independent republic in 1918, the song "Where Is My Homeland" has survived as the national anthem. One of the reasons why it has survived under various regimes might be the fact that it is apolitical, celebrating homeland and the natural beauty of the landscape. It thus also survived the communist regime because it expressed national identity as a secular identity. Therefore, it is mainly the attitude to music which is presented as a feature of Czechness in modern times. Naturally, it is questionable to what degree and if at all music can be considered a substitute for religion or even as a modern manifestation of spirituality. The National Museum's exhibitions seem to confirm, however, this philosophical presupposition. In them, religion is presented as a relic of the past, a lifestyle of previous generations, while music is the modern manifestation of the national mentality, if not even spirituality.

\section{Czechness and Its Relationship to Otherness}

Thinking about the concept of nation, homeland and Czechness make no sense without placing them into the broader context of their relationship to the outside world, to nature and towards other nations. The idea of a nation gains significance particularly in contact with otherness, in discovering the world with all its diversity of nations, cultures, languages, civilizations, as well as in contact with the natural world. This is because the relationship to otherness defines the one defining it, his positioning within the world's diversity.

Czechness and its attitudes to other nations is defined especially on the grounds of these nations' attitudes to the national liberation of Czechs, to Czech desires for an independent state and with regards to other nations' support of the Czech state (or lack of) during the national crisis. As mentioned earlier, the events of the years 1918, 1938, 1945, 1948 and 1989 are considered milestones, in fact as tumbling stones, testing relationships with other nations.

32 English translation available for example at: https://lyricstranslate.com/en/kde-domov-m\%C5\%AFj-where -my-home.html.

33 The second part of the Czechoslovak national anthem was a Slovak song "Lightning over the Tatras". Codified in 1918, the two-part bilingual Czechoslovak national anthem remained the state's official anthem continually until the split of Czechoslovakia in 1993. 
From the point of view of the exhibitions Czech-Slovak / Slovak-Czech Exhibition, Crossroads of Czech and Czechoslovak Statehood and Laboratory of Power relationships to German speaking nations and Russians have been historically strained, and rather complicated with neighbors such as Poles and Hungarians due to various border disputes. In modern times, the attitude to the German nation is above all defined by the Munich Agreement in 1938 and its aftermath. A significant disillusion is also attached to the attitudes to the French and British because of their support of the Nazi occupation of pre-WWII Czechoslovakia despite mutual military agreements. The exhibitions paint a similarly negative picture of the attitude to the Soviet Union, especially after 1948 during the communist era when Czechoslovakia more or less lost its sovereignty and was forced to abandon democracy and a western political orientation. The year 1968 and the military suppression of the Prague spring is also seen as a criterion determining the attitude of Czechs to others. Not only the Soviet army but the armies of the Warsaw Pact, from the neighboring states namely the Polish army, participated in the occupation of Czechoslovakia in 1968.

A positive bond is felt between Czechs and neighboring Slovaks. This has several reasons: the cultural and language proximity, common efforts to create an independent state as well as the peaceful split of Czechoslovakia in 1993. Nevertheless, it is impossible to overlook that in some phases of the existence of Czechoslovakia, the cohabitation was mutually difficult.

The relationship of Czechs to Americans is presented as politically and culturally important. This is not only the result of the significant ex-patriot community in Chicago, the waves of immigration to the USA since the second half of the nineteenth century and especially after 1948 and 1968, but also thanks to the political influence of President Woodrow Wilson on the founding of an independent Czechoslovakia and the participation of American armies in the liberation from Nazism in 1945.

Czechness, however, is not only presented in exhibitions in relationship to culturally close nations. Discoveries of other cultures, nations and ethnic groups, their lifestyles, customs and traditions in the form of traveling rank among the important phenomena of the nineteenth century. Travelers' findings and the items they collected for exhibiting purposes became, in many cases, the foundations of the National Museum's collections. Traveling meant meetings with other cultures, lifestyles, and values and so it went, undoubtedly, hand in hand with the realization of the difference between "us" and "them". The most important travelers and explorers include Emil Holub (1847-1902), who drew reports from his trips, Enrique Stanko Vráz (1860-1932) who already took photographs, and Vojtěch Náprstek (1826-1894) who was also a philanthropist and an active patriot [Šámal 2017].

One of the Museum's long-term exhibitions is dedicated to him. He identified with Czechness already during his secondary school studies under the influence of Joseph Jungmann (1773-1847), the renowned Czech philologist, writer and translator. Náprstek then changed his original name Adalbert Fingerhut, which is a German name, into its Czech variant.

Among other trips and activities, Vojtěch Náprstek spent almost ten years (1848-1857) in the United States. He was an important figure in the Czech social life. Described as a "very sociable, witty and original man, he was an often sought out companion" in whose house important figures of the Czech political and cultural life met - writers, poets, politicians, artists, and thinkers, such as for example the historian František Palacký, the 
composer Antonín Dvořák, or the future President of Czechoslovakia Tomáš G. Masaryk, all figures previously mentioned. Náprstek was also a co-founder of a variety of associations and clubs, such as Sokol, the Czech Tourist (Hiking) Club, the Bohemian Kingdom Museum's Club, the American Ladies Club, as well as the Club for the Erection of a John Hus Monument. Many of these activities were "courageous political-social acts", 34 as the exhibition highlights. Náprstek supported the erection of the Hus monument in Prague despite the fact that such an effort was viewed as socially unacceptable in the mainly Catholic Habsburg Empire as the idea "to build a monument to a heretic" 35 was inadmissible. Náprstek was known, however, for his freethinking attitudes as well as for his critical stance towards the Catholic Church, the Reformation and also Protestant churches [Vlha 2010: 51-72]. When the Club finally managed to defend the idea of the Hus monument, Náprstek actually had the winning proposals for the monument on display in his own house. Given his attitude to religion, however, it can be assumed that his support for the monument was not a pro-Reformation manifestation but of a nationalistic, patriotic stand, a form of identification with Czechness in opposition to Germanness as well as to Catholicism, the Empire and probably as a political provocation.

In 1847, Vojtěch Náprstek founded the Czech Industrial Museum, renamed the Náprstek Museum of Asian, African and American Cultures in 1931 and soon nationalized into a state museum. During its 130-year existence, the Náprstek Museum has created a unique collection of Non-European artifacts with over six thousand items. The Museum currently houses a long-term exhibition entitled Cultures of Australia and Oceania, in which the religious traditions and customs of local indigenous peoples are also contained. The Náprstek Museum was established 130 years ago and its collection from Australia and Oceania contains more than 6000 collection items.

In the opening of this article, the presupposition that our statements about others often reveal a great deal about ourselves (or in fact even more about ourselves than about others) was introduced. This is equally valid for the exhibition on the cultures of Australia and Oceania. The exhibition shares the same approach with the exhibition of Czech Folk Culture, namely that religion is talked about in the past tense and is presented in the ideological framework of the second half of the nineteenth century. One of the labels reads, for example: "Religion was an important element of the life of people in the northwest region of Guinea." The exhibition emphasizes the cult of ancestors ${ }^{36}$ and the cult of fertility. ${ }^{37}$ Interestingly, the exhibition's labels use standard Christian theological terminology to describe religions of these cultures, including the terms supreme god, supernatural or priest. The term aristocracy is used to describe the governing class, specifying that "it was set apart from the process of production", a typically Marxist interpretation. The descriptions of the cultures of Oceania and Australia is in many ways based on the stratification of European

34 The National Museum's long-term exhibition Vojta Náprstek. The exhibition presents Vojtěch Náprstek, his life and work, as well as his family, studies, emigration, activities and travel. The exhibition includes period photographs and documents.

35 The National Museum's long-term exhibition Vojta Náprstek.

36 Herbert Spencer (1820-1903) viewed the so-called cult of ancestors as the first stage in the development of religion, see his System of Synthetic Philosophy. Manism is based on a belief in the after-life and in the power and influence of dead ones over the living.

37 This topic has already been discussed, for example, by Wilhelm Mannhardt, Andrew Lang, Edwin O. James, James G. Frazer, Raffaele Pettazzoni and others. 
society and on the terminology of European science. The exhibition's criticism of European colonization of Oceania and Australia, as well as of Christian missions, is blamed, in contrast for "the rapid cultural decline" and the frequent extinction of various peoples (from New Guinea to New Zealand) can be evaluated positively.

Last but not least, Czechness is defined not only in relation to otherness (be it culturally close or very distant) and to the homeland but to the natural world as well. This topic is covered especially by the natural science exhibition entitled Noah's Ark. ${ }^{38}$ The National Museum sees itself as a kind of Ark because it collects, studies and preserves "the diversity of the animal world for future generations". The Museum therefore "draws attention to modern dangers that put at risk the rich variety of species on our planet". 39 The name of the exhibition is derived from the well-known Biblical story [Gen 6:13-17] in order to point out that there contemporary threats to wildlife. The Biblical reference is used here, however, not for its religious but only for its moral significance. One of the labels in the exhibition even emphasizes that "despite the fact that modern man no longer thinks in biblical categories", 40 he nonetheless has not changed his attitude and behavior towards the world much. The Museum's visitors are repeatedly reminded that religion is a matter of the past and does not have much of a place in the current national narrative.

The Noah's Ark exhibition, however, wants to warn "against the consequences of human behavior" 41 and appeals to visitors to adopt a responsible attitude to the surrounding world because, due to human irresponsibility, natural beauty, the nation, and the homeland can easily be put in danger. It is important to preserve it. In this new exhibition, a clear shift is apparent in the values and approach to nature in comparison with the exhibition Czech Folk Culture, which speaks of "conquering" and "subduing" 42 nature. The new approach is based on the attempt to form a national identity by means of a responsible relationship to the natural world, to the whole.

\section{Conclusion}

By studying religion and non-religion in the Czech National Museum, one can see not only how this institution presents its attitude to world-views, but at the same time points to larger social-political changes in modern Czech society. These are the results of not only cultural, but mainly political changes due to which religion ceased to play the role of social and cultural cement, of state ideology. Discontinuity in the political sphere in this country, during the transformation from a monarchy to a democracy, from a democracy to totalitarian regimes and then back to a democracy profoundly influenced the re-evaluation of the importance of religion in both political and social lives. The experience with communist ideology had a deep impact on changes in world-views within Czech society of the twentieth and twenty-first centuries. The state and its institutions turned from the position of preservers of religion, as it was under the monarchy, to a more or less neutral

\footnotetext{
38 Noah's Ark. Welcome On Board! New long-term exhibition of the National Museum.

39 Ibid.

40 Ibid.

41 Ibid.

42 Czech Folk Culture. Long-term exhibition of the National Museum.
} 
position in democracies and to the extreme position of critics and persecutors of religion under communist rule. Over its 200 years of existence, the National Museum as an institution has had to adapt, often uneasily, to frequent changes in state politics and changing attitudes to issues of world-view in general.

The current long-term exhibitions were mostly created after 1989 . The picture of religion and non-religion they present to their visitors has been formed by oscillating between the interests of the state on the one hand and the needs of the nation and the mission of a scientific institution on the other. It is thus quite surprising that the Museum has maintained for a long time a rather unified attitude towards religions. This might perhaps be due to the fact that religion plays a minor (possibly too marginal) role in the narrative as presented by the Museum. Its presentation is somewhat outdated, however, in accordance with the views and attitudes of the educated elites of the nineteenth century rather than the contemporary situation, i.e. the real place of religion in the lives of Czechs. In other words, the idea that religion is a gradually dying cultural and social relic which has long lost its social significance, is also a relic.

Czech national identity to a degree also stems from a negative attitude to religion, especially to Catholicism. From this point of view, it is also surprising that anti-clerical or atheist approaches and movements are practically not represented in the Museum at all. Only a few signs in the exhibitions reveal that they might be remnants of previous, possibly Marxist, thinking. In other words, expressions and manifestations of anti-religious attitudes as world-views play an even more insignificant role in the narrative than religion itself. This might be caused by the tendency of the Museum, as a state and scientific institution, to take a neutral stand just as it can be caused by its tendency to avoid historically and ideologically laden topics.

Far more interesting therefore is the secular, non-religious image of Czechness presented in the Museum's narrative and not formed in opposition to religion, Such a concept emphasizes politically and artistically grounded and generally humanistic Czechness. At the same time, it should be pointed out that the concept of Czechness is not presented in a nationalistic or xenophobic manner but is rather sober, realistically assessing the historical importance of others (meaning neighboring nations) and their support for (or resistance to) Czech national liberation and political autonomy. Religion thus plays no significant role in the evaluation of us nor of others, with the sole exception of the communist dictatorship. One can therefore state that the picture of Czechness and Czech patriotism in the National Museum, although it may appear to some as incomplete, certainly does not encourage unhealthy patriotism.

\section{Bibliography}

Amarasingam, Amarnath (ed.) [2010]. Religion and the New Atheism. A Critical Appraisal. Leiden: Brill. Botton de, Alain [2013]. Religion for Atheists: A Non-believer's Guide to the Uses of Religion. Vintage. Bubík, Tomáš [2010]. České bádání o náboženství ve 20. století. Červený Kostelec: Pavel Mervart.

Buggeln, Gretchen - Paine, Crispin - Plate, S. Brent [2017]. Introduction: Religion in Museums. Museums as Religion. In. Religion in Museums: Global and Multidisciplinary Perspectives. Bloomsbury.

Bullivant, Stephen - Ruse, Michael (eds.) [2013]. The Oxford Handbook of Atheism. Oxford university Press. 
Gervais, Will M. - Willard, Aiyana K. - Norenzayan, Ara - Henrich, Joseph [2011]. The cultural transmission of faith. Why innate intuitions are necessary, but insufficient, to explain religious belief. Religion 41 (3): 389-410.

Hanuš, Josef [1921, 1923]. Národní museum a naše obrození. Prague: Národní muzeum.

Henrich, Joseph [2009]. The evolution of costly displays, cooperation and religion: credibility enhancing displays and their implications for cultural evolution. Evolution and Human Behavior 30 (4): 244-260.

Hromádka, Josef L. [1930]. Masaryk. Prague: YMCA.

Lee, Lois [2017]. Non-Religion. In. The Oxford Handbook of the Study of Religion (ed. Michael Stausberg and Steven Engler). Oxford University Press.

Levitt, Peggy [2015]. Artifacts and Allegiances: How Museums Put the Nation and the World on Display. University of California Press.

Lužný, Dušan - Váně, Jan [2017]. Koncept kolektivní paměti - základní východiska a závěry. Historický časopis 65 (4): 577-590.

Masaryk, Tomáš G. [1990]. Ideály humanitní. Prague: Melantrich.

McCutcheon, Russell T. (ed.) [1999]. Insider/Outsider Problem in the Study of Religion (Controversies in the Study of Religion). London - New York: Cassell.

Ngo, T. - Quijada, J. (eds.) [2015]. Atheist Secularism and its Discontents. A Comparative Study of Religion and Communism in Eurasia. Palgrave MacMillan.

Sklenář, Karel [2001]. Obraz vlasti, př́běh Národního muzea. Prague: Paseka.

Smetana, Augustin [1903]. Úvahy o budoucnosti lidstva. Prague: Jan Laichter.

Šámal, Martin [2017]. Jsem svobodný... Prague: Národní muzeum.

Štolfa, L. [1927]. Za novým náboženstvím. Prague: Unitaria.

Vlha, Marek [2010]. Vojta Náprstek a Antonín Dignowity: ideový svět dvou náboženských svobodomyslníků $v$ počátcích krajanské Ameriky. Studia historica brunensia (57): 51-72.

Woitschová, Klára [2019]. Dějiny Národního muzea na pomezí historiografických žánrů. Muzeológia a kultúrne dedičstvo 7 (1): 83-98.

Zuckerman, Phil (ed.) [2010]. Atheism and Secularity. Santa Barbara: ABC-CLIO.

Tomáš Bubík is Associate Professor at Palacký University Olomouc in the Czech Republic where he heads the unit for the Study of Religion at the Faculty of Arts. His research interests are history, theory and methodology of the study of religions, study of modern forms of atheism and non-religion and lately cognitive study of religions. He is currently responsible for two research projects: one is focused on the cognitive study of religion and on building a cognitive team and lab. He is concurrently working on the project Freethought, Atheism and Secularization in Central and Eastern European Countries in the Twentieth Century, a project that includes 15 specialists in the field from 12 countries in Central and Eastern Europe. Bubik has been president of the Czech Society for the Study of Religions since 2015 and 2018. 